\title{
NOTES
}

\section{WHITMAN, WARNER, AND THE AMERICAN MEN OF LETTERS SERIES}

Modeling it on the highly successful English Men of Letters series, the Boston publisher Houghton Mifflin in 1880 started its own American Men of Letters series. For a few months the project was under the direction of James T. Fields. At his death in 1881, however, the series was put in the hands of the popular novelist and essayist Charles Dudley Warner. He would be in charge until his own death in 1900. During Field's short tenure he was able to secure only one book, Horace Scudder's Noah Webster. Most of the other titles in this series, which would eventually run to nineteen volumes, were brought out under Warner.

One volume that was not brought out under Warner, however, was the Walt Whitman book. And there was a good reason for that: Warner would not have Whitman in the series. It was not until 1906, six years after Warner's death, that Bliss Perry's Walt Whitman would appear. Its long delay called for an explanation, which Perry offered in his preface: "The publishers of this book hoped for many years that Mr. John Burroughs, one of Walt Whitman's oldest friends, would write Whitman's Life. As other literary engagements prevented Mr. Burroughs from carrying out this plan, I was asked to undertake the present volume."1

That Burroughs had not been able to produce the book, however, was only part of the story. In fact, Burroughs, whose Whitman: A Study was published by Houghton Mifflin in 1896, was not the publishers' first choice for the task, as the following letter from Warner to the editors at Houghton Mifflin indicates:

57 Forest St.

Hartford, Conn.

May 151898

\section{Dear Sirs, ${ }^{2}$}

The suggestion in your note of May 10 is the first I have heard of including Walt Whitman in the Series, and of inviting Mr. Salter to prepare the volume. I do not know Mr. Salter or his work, unfortunately for me. ${ }^{3}$

As to the series proposition, I should like to confer with you. To me his name still stands in doubt.

Whatever he is, could you in any way call him a Man of Letters?

If he is a genius, is he a poet? He defies all form. I recognize genius in places. But he was an awful poser. Some time before his death, when he was supposed to be in destitution, Mr. Cary of the Century, at great trouble, organized readings for him in New York, and raised some money. ${ }^{4}$ When he died it was found that he saved up about $\$ 5000$ to build himself a monument! ${ }^{5}$

If he must go into our Series, I should not wish to have him treated by one of his abject worshipers, who repudiates our whole idea of the difference between poetry and prose, in order to admit him among the poets. ${ }^{6}$

I hope I can confer with you before long.

\section{Yours sincerely, \\ Chas. Dudley Warner}


Warner's letter put an end to the matter, at least temporarily, for penciled at the bottom of the second page of Warner's letter are the initials "WHP" followed by the notation "No answer." The initials are those of Walter Hines Page, an editor in the Houghton Mifflin office doubling as the editor of the Atlantic Monthly.

Brown University

GEORge MONTEIRO

\section{NOTES}

1 Bliss Perry, Walt Whitman (Boston and New York: Houghton Mifflin, 1906), p. v.

2 Ms. Houghton Library, Harvard University. Its contents are reproduced here with the permission of the Houghton Mifflin Company and the Library's consent.

3 Probably William Mackintire Salter, the author of "The Great Side of Walt Whitman," Ethical Addresses (September 1899), series 6, no. 7, 121-144; reprinted along with "The Questionable Side of Walt Whitman" as Walt Whitman: Two Addresses (Philadelphia: S. Burns Weston, 1899).

4 Probably Edward Cary, a trustee of the Century Association, New York, and a sometimes member of that club's Committee on Literature.

5 In 1885 Warner had himself contributed to a subscription on Whitman's behalf (Perry, pp. 250-251).

6 Compare Warner's comments on Whitman in 1896: "I wish I could sing the crow! No poet has ever done it, not even Walt Whitman, who might have had a surer hold on immortality by singing the crow than by singing himself" ("Editor's Study," Harper's Magazine [May 1896], 92:961).

\section{“TRANSLATING THE UNTRANSLATABLE": A NOTE ON "THE MYSTIC TRUMPETER"}

"The Mystic Trumpeter," written in 1872 and published in As a Strong Bird on Pinions Free, deserves consideration as a major poem of Whitman's later years. The poem demonstrates the role of the prophetic bard, and the possibility of transcendence from the physical world to a higher reality: it illustrates how music expresses that experience of the higher reality more accurately than does verbal language. Readers of Whitman's poetry are familiar with his conception of the poet as "divine litteratus" who enacts a vision of a New World and as translator of a universal poetry generated before the advent of time. But what in Whitman's early poetry is a quasi-ventriloquist expression of the Self, a belief in the "valvéd voice" of the Soul, is in "The Mystic Trumpeter" something more.

At first glance, the poem is a channel for the poet to transmit a message to his listeners. In Section 1 the poet even states his intention to translate the "capricious tunes" of the "strange musician." To this end he beckons the "wild trumpeter" to come nearer so that his ears alone may "catch thy notes." Despite this resolve to follow the lead of the trumpeter, the poet quickly assumes control over the scenario 